\title{
Separate Entity of Parent and Subsidiary Corporations
}

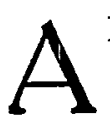

$\mathrm{N}$ important question in corporation law is the effect of the connection between a parent corporation and its subordinate

branches, or subsidiaries. When will they be found joined in a union so close as to amount to practical identification, so that the formal separation of legal entities will be disregarded? What system of control exercised by a corporation over its subsidiaries will involve responsibility for their acts and contracts as for those of an agent? One aspect of this many sided question relates to jurisdiction over foreign corporations. A foreign corporation can be personally served with process only when it is doing business within a state. ${ }^{2}$ In a recent United States Supreme Court case the issue was considered whether the use of a subsidiary to transact business in a state will subject the parent corporation to the jurisdiction. ${ }^{2}$ The Cudahy Packing Company, a Maine corporation, used as an instrumentality to market the Cudahy products within the State of North Carolina, the Cudahy Packing Company of Alabama. Process was served upon the process agent of the Cudahy Company of Alabama and the plaintiff undertook to establish identity between the defendant, the Maine corporation and its subsidiary, the Alabama corporation. The latter bought from the defendant and sold to dealers. Goods packed by the defendant in Iowa were shipped direct to dealers and the Alabama corporation collected the price. Through ownership of the entire capital stock and otherwise the parent corporation dominated the Alabama corporation completely and exerted its control in substantially the same way, and through the same officers, as it did over those selling branches or departments of its business not separately incorporated which were established to market the Cudahy products in other states. But the technical existence of the Alabama Company as a distinct corporate entity was observed. Its organization was separately kept up, and all transactions between the two corporations were represented by

1 Riverside. etc. Mills v. Menefee (1915) 237 U. S. 189, 59 L. Ed. 910,35 Sup. Ct. Rep. 579; 35 Harvard Law Review, 87; 32 Harvard Law Reviev, 871,$879 ; 37$ Harvard Law Review, 825.

2 Cannon Mfg. Co. v. Cudahy Packing Co. (1925) 69 L. Ed., Adv. Ops. 308, 45 Sup. Ct. Rep. 250; see 20 Illinois Law Review, 281. 
entries in their respective books. This corporate separation from the general Cudahy business was evidently adopted because the defendant wished to have business transactions in North Carolina, but did not choose to enter the state in its corporate capacity. It preferred to employ a subsidiary corporation. Was it not carrying on part of its business through the subsidiary company?

The court held that it was already established law that the use of a subsidiary does not necessarily subject a parent corporation to the jurisdiction of the state. The present case, it was said, differs perhaps in degree from previous cases, in that the identity of interest was more complete and the exercise of control over the subsidiary more intimate than in prior cases. The corporate separation, though merely formal, was however, respected for jurisdictional purposes. A subsidiary transacting business in a state, though a mere adjunct or instrumentality of a foreign corporation which owns and controls it, is a separate entity so that the foreign corporation is not doing business there itself. The court distinguishes cases dealing with the matter of jurisdiction over a foreign corporation from other classes of cases where there is an attempt to hold the parent liable for an act or omission of its subsidiary, or to enforce against a subsidiary a liability of the parent. Such cases are referred to as concerning substantive rights rather than procedure.

It had been held on the other hand by the Texas court that a foreign railway company might be sued in a state and county in which it was doing business through the instrumentality of a domestic corporation which operated a line of railway connecting with the foreign corporation's line. The foreign corporation was considered to be doing business in the state through the local company as its representative, and was liable to suit for personal injury by service of process on the officers of the local company. The principal corporation, it was held, was really represented by the agents of the subsidiary corporation and liable the same as if the business had been done in its name. ${ }^{3}$ It must, however, now be

8 Buie v. Chicago R. I. \& P. Ry. Co. (1901) 95 Tex. 51, 65 S. W. 27 ; Central Life, etc. Co. v. Smith (1916) 236 Fed. 170, commented on in 15 Michigan Law Review, 442; In re San Antonio L. \& I. Co. (1916) 228 Fed. 984; Colonial Trust Co. v. Montello Brick Works (1909) 172 Fed. 310; see R. H. Herron Co. v. West Side Elec. Co. (1912) 18 Cal. App. 778, 124 Pac. 455. In a later Texas case, however, this doctrine was repudiated in riew of the fact that it had been otherwise decided by the United States Supreme Court, which is the final authority upon the question of jurisdiction; see 6 Minnesota Law Review, 309 and cases, infra, n. 4. 
recognized in all states that an auxiliary company is not to be treated as the representative of the parent company, nor are its agents to be regarded as agents of the parent company for the purpose of service of process, nor is the parent corporation "doing business" through the subsidiary."

The jurisdiction taken of foreign corporations flows from the fact that the corporation itself does business in the state in such a manner, and to such an extent that its "actual presence" there is established.5 This theory of "presence" like the earlier theory of "implied consent" seems a mere fiction or figure of speech. The real basis of jurisdiction is such a course of business activity by corporate agents that it is deemed fair, politic and reasonable to make the corporation subject to suit there. The "presence" test itself calls for a test and no more definite test has been prescribed than that the acts done must constitute some part of the ordinary business of the corporation and must be continuous or of some duration. ${ }^{6}$

The doctrine that the parent corporation is not deemed to be doing business through its subsidiaries, in the eye of the law, may be regarded as a somewhat technical rule adopted from practical reasons of policy to limit the somewhat arbitrary power exercised by the various states over foreign corporations. Our federal system making every corporation created in one state foreign to every other state often renders it advisable to organize corporations in many different states which are simply branches of the same concern. The relation between dominant and subsidiary corporations while not a basis for jurisdiction over a foreigu corporation, may be treated as an entirely different question in considering such issues as the liability of the holding company for the debts, contracts or torts of the subsidiary, or the right of creditors of a bankrupt holding corporation to reach assets in the hands of a subsidiary, or the

4 Peterson v. Railway Co. (1907) 205 U. S. 364. 51 L. Ed. 841, 27 Sup. Ct. Rep. 513; Proctor \& Gamble v. Newton (1923) 289 Fed. 1013, 1016; Atchison v. Stevens (1918) 109 Tex. 269, 206 S. W. 921 ; Pecos Co. v. Cox (1913) 106 Tex. 74, 157 S. W. 745. But see Cutler v. Cutler-Hammer Mfg. Co. (1920) 266 Fed. 388, where it was said that the subsidiary seems to have amounted to little more than a bookkeeping arrangement.

5 Bank of America v. Whitney Cent. Nat. Bank (1923) 261 U. S. 171, 67 L. Ed. 594, 43 Sup. Ct. Rep. 311.

${ }^{B}$ Farmers, etc. Bank v. Federal Reserve Bank (1922) 286 Fed. 566, 588; 30 Harvard Law Review, 676; 32 Harvard Law Review, 871, 881; 36 Harvard Law Review, 327; 37 Harvard Law Review, 825, 826; 33 Yale Law Journal, 547. 
right of a parent company to prove claims against a subsidiary in bankruptcy in competition with other creditors.

In numerous cases it is contended that a subsidiary corporation is so far owned and controlled by another as to make the parent corporation responsible for the acts and obligations of the subsidiary. Unfortunately it does not seem to be possible to lay down any definite test as to when the usual immunity of the stockholder should be disregarded, but the courts assign various grounds which to a great extent are vague and illusory. It may be found in the first place that in substance the relation of principal and agent exists between the two corporations. It is often said, secondly, that one corporation is the mere "agency", "adjunct", or "instrumentality" of the other, as if this were something different from principal and agent. In other cases the courts speak of the two corporations as being the same identical concern under different names by reason of the mingling or confusing of their business affairs, as where one is merely the selling agency of the other. In other cases the courts purport to go only on the ground of prevention of fraud, evasion and illegality.

Since it is not possible to lay down broad and positive doctrines or rules, it may be useful to collect and classify some of the apparently conflicting cases in this legal quagmire according to their subject matter, citing those which do and those which do not impose liability on the parent or otherwise treat the two concerns as identified. In numerous cases the holding company has been held liabie for the contracts and debts of its subsidiary. ${ }^{7}$ In other cases the holding company is held not liable unless the relation of principal and agent exists. ${ }^{8}$ In many cases a parent corporation has been

7 In the following cases the holding company was held liable for the debts of its subsidiary: Fourth Nat. Bank v. Portsmouth Cotton, etc. Corp. (1922) 280 Fed. 879, 284 Fed. 718; Iuckenbach S. S. Co. v. W. R. Grace Co. (1920) 267 Fed. 676 , 681 (complete dominance, puppet, business intermingled); Stark Electric R. Co. v. McGinty Contracting Co. (1917) 238 Fed. 657 ; U. S. v. United Shoe Machinery Co. (1916) 234 Fed. 127 (subsidiary merely selling or leasing department of parent corporation which is liable for its acts) noted in 15 Michigan Law Review, 78. . Compare Proctor \& Gamble v. Newton, supra, n. 4; Interstate Tel. Co. v. Baltimore Tel. Co. (1892) 51 Fed. 49, 54 Fed. 50; Dillard \& Coffin Co. v. Richmond Cotton Oil Co. (1918) 140 Tenn. 290, 204 S. W. 758 (parent liable for debts of dummy, complete control); Platt v. Bradner (1924) 131 Wash. 573, 230 Pac. 633 (mere agency of owning company); see Kelly v. Ning Yung Ben. Assn. (1905) 2 Cal. App. 460, $84 \mathrm{Pac} 321$ (services rendered at instance of officer of parent corporation).

${ }^{8}$ In the following cases the holding company was held not liable for the debts of the subsidiary: City of Holland v. Holland City Gas Co. (1919) 257 Fed. 679; New York Trust Co. v. Carpenter (1918) 250 Fed. 668; Martin v. 
held liable for the negligence and other torts of the subsidiary. ${ }^{\circ}$ In other cases the parent corporation is held not liable. ${ }^{10}$ In certain cases the assets of the subsidiary are held to be assets of the bankrupt parent corporation and creditors of the parent may enforce their claims against them.11

The question is sometimes raised whether the parent corporation can prove its claims against the insolvent subsidiary in competition with its creditors. A few cases have gone so far as to hold that where the parent corporation has conducted its business through the instrumentality of the subsidiary that capital advanced may not be treated as a loan to the subsidiary as against third parties. The controlling corporation, it has been contended, cannot share as a creditor in the assets of the insolvent subsidiary, on the theory that the parent which invests money in a branch of its own business cannot in case of failure shift the loss to innocent parties, or enforce a claim against itself. ${ }^{12}$

Development Co. (1917) 240 Fed. 42; Chicago, Pittsburg \& Buffalo Co. v. Duncan (1916) 232 Fed. 584; Richmond, etc. Co. v. Richmond Co. (1895) 68 Fed. 105 ; Marsch v. S. N. Eng. R. Corp. (1918) 230 Mass. 483,120 N. E. 120 ; Borough of Ambridge v. Philadelphia Co. (1925) 283 Penn St. 5,129 Atl. 67.

9 Parent corporation liable for torts: Gulf C. \& S. F. Ry. Co. v. Cities Service Co. (1922) 281 Fed. 214; The Willem Van Driel Senior (1918) 252 Fed. 35, 164 C. C. A. 147; Joseph R. Foard Co. v. Maryland (1914) 219 Fed. 827, 135 C. C. A. 497 (business not kept separate; funds of subsidiary dealt with as if they were parent's); Maryland v. General Stevedoring Co. (1914) 213 Fed. 51 ; Westinghouse Elec. \& M. Co. v. Allis Chalmers Co. (1910) 176 Fed. 362; Lehigh Valley R. Co. v. Du Pont (1904) 128 Fed. 840; Lehigh, etc. R. Co. v. Delachesa (1906) 145 Fed. 617, 76 C. C. A. 307; Erickson v. Minn. \& Ont. Power Co. (1916) 134 Minn. 209, 158 N. W. 979 ; Specht v. Missouri Pac. R. R. Co. (1923) 154 Minn. 314, 191 N. W. 905 (principal and agent); Auglaize Box Board Co. v. Hinton (1919) 100 Ohio St. 505, 126 N. E. 881, 885; Oriental Inv. Co. v. Barclay (1901) 25 Tex. Civ. App. 543, 64 S. W. 80 (principal and agent).

${ }^{10}$ In the following cases the parent corporation was held not liable for the negligence or tort of the subsidiary: Union Sulphur Co. v. Freeport Texas Co. (1918) 251 Fed. 634, 661 ; Atchison, etc. R. R. Co. v. Cochran (1890) 43 Kans. 225. 23 Pac. 151; Stone v. Cleveland D.; C. \& St. L. Ry. Co. (1911) 202 N. Y. 352, 95 N. E. 816, 35 L. R. A. (N. S.) 770. See Bethleliem Steel Co. v. Raymond Concrete Pile Co. (1922) 141 Md. 67, 118, Atl. 279.

11 Re Eilers Music House (1921) 270 Fed. 915, 274 Fed. 330; Re Rieger (1907) 157 Fed. 609; Re Muncie Pulp Co. (1905) 139 Fed. 546, 71 C. "C. A. 530 (subsidiary used as a mere agent or creature of the bankrupt with no independent or separate business existence); B. \& $\mathrm{O}$. Tel. Co. v. Interstate Tel. Co. (1893) 54 Fed. 50, 4 C. C. A. 184 (judgment creditor of parent reaches funds realized from sale of plant of subsidiary); Day v. Postal Tel. Co. (1887) $66 \mathrm{Md}$. 354, 7 Atl. 608 (dominant corporation managed subsidiary without regard to interests of its shareholders).

12 Hunter v. Baker Motor Vehicle Co. (1915) 225 Fed. 1006, 1015; Clere Clothing Co. v. Union Trust, etc. Bank (1915) 224 Fed. 363,140 C. C. A. 49; S. G. V. Co. v. S. G. V. Co. (1919) 264 Penn. St. 265, 107 Atl. 721 ; but see contra: Pickett v. Wood (1916) 234 Fed. 833, 148 C. C. A. 431 ; Re Water- 
The control of parent over subsidiary may be a ground for treating terminal facilities operated by a subsidiary as not being an independent public carrier, free to impose separate carrying charges on the public. This formal breaking up of a continuous line may be a mere sleight of hand trick with the separate legal entity. ${ }^{13}$ So a subsidiary wharfage company cannot escape regulation by the Commerce Commission on the ground that it is a separate entity where it was an essential link in a system controlled by a railroad company, an interstate carrier. ${ }^{14}$ A parent company having control of a subsidiary company occupies a fiduciary relation toward the company, its stockholders and creditors. ${ }^{15}$

The mere fact that the parent corporation owns all the stock of the subordinate corporation, or that the same individuals own all the stock in both corporations, does not make them the same concern in law. There must be some ground in addition to mere unity of interest and ownership. Even when two or more corporations are associated together under common control as several branches or departments of a single common enterprise, they are still normally to be regarded as separate and independent legal entities.

It has been asserted, however, that where stock ownership is resorted to not for the purpose of participating in the affairs of the corporation in the customary and usual manner, but for the purpose of controlling the subsidiary company so that it may be used as a mere adjunct, agency or instrumentality of the owning company, the court will not permit itself to be blinded by mere corporate form, but will in a proper case disregard the corporate entity and treat the two corporations as one, or at least as responsible for each other. ${ }^{16}$

town Paper Co. (1909) 169 Fed. 252, 94 C. C. A. 528 (separate corporate organization and books maintained); see 15 Michigan Law Review, 172.

${ }^{13}$ Chicago M. \& St. P. R. Co. v. Minn. Civic, etc. Assn. (1918) 247 U. S. 490, 62 L. Ed. 1229, 38 Sup. Ct. Rep. 553.

14 Southern Pac. Term. Co. v. I. C. C. (1911) 219 U. S. 498, 55 L. Ed. 310, 31 Sup. Ct. Rep. 272 . See also State v. Chicago \& N. W. R. Co. (1916) 133 Minn. 413,158 N. W. 627 (one road or line).

16 Title Ins. \& T. Co. v. Cal. Dev. Co. (1915) 171 Cal. 173, 152 Pac. 542.

${ }^{16}$ Chicago M. \& St. P. R. Co. v. Minneapolis Civic \& Comm. Assn. (1918) 247 U. S. 490, 62 L. Ed. 1229, 38 Sup. Ct. Rep. 553; Radio Craft Co. v. Westinghouse Elec. and M Mg. Co. (1925) 7 Fed. (2d) 432; Hunter v. Baker Motor Vehicle Co. (1915) 225 Fed. 1006; Advance-Rumley Thresher Co. v. Geyer (1918) 40 N. D. 18, 168 N. W. 731; Platt v. Bradner Co. (1924) 131 Wash. 573, 230 Pac. 633, 634; 1 Fletcher, Cyc. of Corporations, p. 63, \& 45; 10 Fletcher, Cyc. of Corporations, p. 11, \& 45; see Wenban Estate v. Hewlett (1924) 193 Cal. 675, 227 Pac. 723; 12 Columbia Law Review, 502, 503. 
In a recent Massachusetts case ${ }^{17}$ the Finnish Socialistic Publishing Company organized a subsidiary for the sole purpose of publishing a newspaper and to manage and use it is a creature or mouthpiece for the circulation of its propaganda. A libel was published in the paper without the immediate knowledge of the parent company. It was held that "this technical distinction as between themselves cannot be invoked to defeat the plaintiff to whom they are jointly and severally responsible". ${ }^{17 / 3}$

What is meant by such terms as "adjunct", "agency", "instrumentality", "creature" or "mouthpiece"? What conditions must exist to warrant a court in treating the A corporation as the mere adjunct of the B corporation? The word "agency" is often used as a synonym of "adjunct", whatever that may mean, and as descriptive of a relation variously defined in the cases as "alter ego", "alias", "device", "dummy", "branch", "tool", "corporate double", "business conduit", "instrumentality", etc., but all in the sense of "means" through which a corporation's own business is actively prosecuted. It clearly appears that the word "adjunct" and these other terms like "business conduit", are too uncertain to be adopted as a test or rule of law to indicate when adherence to the doctrine of separate and distinct corporate entity will work injustice or amount to a perversion of corporate capacity. ${ }^{18}$

One corporation may be the agent of another, just as one individual may act for another. The difficult question is what facts of ownership, control, and management in a common enterprise should require that the acts and obligations and property of the subsidiary should be treated as if they were those of the parent. ${ }^{20}$ It is submitted that no mechanical rule based on objective facts of control or connection which will furnish a certain test is possible of formulation. Identity of stockholders, identity of officers, the manner of keeping books and records, the methods of conducting the corporate business as a separate concern or as a mere department of the other concern, may be evidential facts to be considered as bearing on the question of juggling of separate capacities and whether the subsidiary is being

17 Finnish Temperance Society v. Finnish Socialistic Publishing Co. (1921) 238 Mass. 345, 130 N. E. 845. Cf. Marsch v. Southern N. E. R. Co. 230 Mass. 483,120 N. E. 120.

17/2 Finnish Temperance Society v. Finnish Socialistic Publishing Co., 238 Mass. 345, 355 .

18 N. Y. Trust Co. v. Carpenter (1918) 250 Fed. 668, 163 C. C. A. 14; 32 Harvard Law Review, 424 ; but see Wormser, 12 Columbia Law Review, $503,504$.

${ }_{19}$ See Erickson v. Minn. \& Ont. Power Co. (1916) 134 Minn. 209, 158 N. W. 979 ; Advance-Rumley Thresher Co. v. Geyer, supra, n. 16. 
managed in such a way as to make the controlling corporation justly responsible. ${ }^{20}$ But after all it comes down to a question of good faith and honesty in the use of the corporate privilege for legitimate ends. If a corporation is owned and controlled by another and is manipulated by the owner for its own purposes and in its own interests to the prejudice of innocent third parties, or the public welfare, it may be necessary to limit such abuse of the corporate capacity or shield. But in the ordinary case the fact that the shares of one company all belong to another does not make the subsidiary a mere alias, or trustee or agent for the parent company or for the shareholders of the parent company. The relationship is that of shareholder to corporation and does not constitute the subsidiary an agent.

The primary object of organization of corporations and the value of the corporate privilege depend on the separation of capacities, and on the fact that although the corporation acts for its stockholders, its stockholders are not personally liable for its acts. ${ }^{21}$ In a popular sense the company may in every case be said to carry on business for and on behalf of its shareholders, but this does not in point of law constitute the relation of principal and agent between them or render the shareholders liable for acts of the company or the debts which it incurs. ${ }^{22}$ The motive of the parent corporation to secure authority to do business with limited liability is not a dishonest use of the corporate privilege. $^{23}$ It is nevertheless true that if the separate corporate capacity is perverted to dishonest uses to evade obligations or to defeat public welfare, the courts will penetrate the device, uncover the abuse of the special privilege, and circumvent fraud. ${ }^{24}$ But to justify treating the sole stockholder

${ }^{20}$ See notes in 4 Minnesota Law Review, 219; 29 Yale Law Journal, 663. 21 Gramaphone, etc. Ltd. v. Stanley [1906] 2 K. B. 856; Salomon v. Salomon \& Co. [1897] App. Cas. 22, 43; Sloan Shipyards Corp. v. U. S. Shipping Board (1922) 258 U. S. 549, 66 L. Ed. 762, 42 Sup. Ct. Rep. 385. Contracts made by the Fleet Corporation for work on ships are enforcible against it though U. S. is sole stockholder. Although an instrumentality of the U. S. it was not immune from suit. Providence Engineering Corp. v. Downey, etc. Corp. (1923) 294 Fed. 641; 36 Harvard Law Review, 218; 8 Minnesota Law Review, 427 ; cf. Ballaine v. Alaska Northern Ry. Co. (1919) 259 Fed. 183.

22 See note 32 Harvard Law Review, 424, commenting on N. Y. Trust Co. v. Carpenter, supra, n. 18.

23 Elenkrieg v. Siebrecht (1924) 238 N. Y. 254,144 N. E. 519, 34 A. L. R. $592,597 \mathrm{n}$.

24 U. S. v. Reading Co. (1920) 253 U. S. 26,64 L. Ed. 760, 40 Sup. Ct. Rep. 425; Linn \& Lane Timber Co. v. U. S. (1915) 236 U. S. 574, 59 L. Ed. 725; 35 Sup. Ct. Rep. 440; U. S. v. Lehigh Valley R. R. Co. (1911) 220 U. S. 257,55 L. Ed. 458, 31 Sup. Ct. Rep. 387; U. S. v. Milwaukee Transit Co. 
or holding company as responsible it is not enough that the subsidiary is so organized and controlled as to make it "merely an instrumentality, conduit or adjunct" of its stockholders. It must further appear that to recognize their separate entities would aid in the consummation of a wrong. ${ }^{25}$ If the sole stockholder of a corporation sets fire to its property in order to get the insurance, his act would be a defense to a suit for the insurance. He could not be allowed to profit in his corporate capacity by a fraudulent act done in his individual capacity. The law does not suffer itself to be circumvented by specious devices or disguises. ${ }^{26}$ An executor who fails to sue a corporation of which he is sole stockholder cannot take advantage of his breach of duty to set up the statute of limitations, the corporate debt being in substance his own. It would be an abuse of the privilege of separate capacity. ${ }^{27}$

The basic theory of corporation law is that a corporation exists as an entity entirely apart from its stockholders. There is in many cases much loose talk about "iguoring the corporate fiction" and "looking at the substance rather than the form." But the corporate capacity is a legal fact, not a fiction. Problems of responsibility for fraud or for the acts of a corporation used as an agent are to be solved not by "disregarding" the corporate personality, but by the application of the usual principles of liability for the acts of other persons or for collusion with them. Before the acts and obligations of a corporation can be legally recognized as those of particular individuals, and vice versa, it must appear that the circumstances are such that there is an agency of the one for the other or that the privilege is being abused so that an adherence to the distinction or separate capacity would sanction a fraud or promote injustice.

A subsidiary corporation is simply a species of one man corpora-

(1905) 142 Fed. 247 (dummy used to obtain rebates); Rice v. Sanger Bros. (1924) Ariz. 229 Pac. 397; Gardner v. Treasurer (1916) 225 Mass. 355, 367, 114 N. E. 617. See McWilliams, Limitations in the Theory of Corporate Entity in California, 4 California Law Review, 465; Disregarding Corporate Entity in One Man Company, 13 California Law Review, 496; Canfield, Scope of Corporate Entity Theory, 17 Columbia Law Review, 128;

Wormser. Piercing Veil of Corporate Entity, 12 Columbia Law Review, 496. 25 Erkenbrecher v. Grant (1921) 187 Cal. 7, 200 Pac. 641; Minifie v. Rowley (1921) 187 Cal. 481, 202 Pac. 673.

26 Meily Co. v. London, etc. Fire Ins. Co. (1906) 148 Fed. 683; Wabash Ry. Co. v. American, etc. Co. (1925) 7 Fed. (2d) 335; D. I. Felsenthal Co. v. Northern Assurance Co., Ltd. (1918) 284 I11. 343, 120 N. E. 268, 1 A. L. R. 602 (disregarding corporate existence); Kirkpatrick v. Allemannia F. Ins. Co. (1905) 102 App. Div. 327, 92 N. Y. Supp. 466.

${ }^{27}$ Minifie v. Rowley, supra, n. 25. 
tion. But the concentration of its stock in the hands of one holder does not dissolve the corporation or put its entity into a state of suspense. There are a number of cases invoving "one man" corporations, where the court holds the sole stockholder liable for the acts of the corporation, or holds the corporation bound by the act of the sole stockholder. The language of the opinions often places the decision on "disregard of the corporate entity," but most of them can be explained by a liberal application of ordinary agency rules, such as holding the corporation bound by the act of those in control, though without the usual formalities of a directors' meeting. ${ }^{28}$

School of Jurisprudence, Henry W. Ballantine. University of California.

28 Wenban Estate v. Hewlett, supra, n. 16; Campbell v. Hanford (1924) 227 Pac. 234 (Cal.), noted in 24 Columbia Law Review, 798; Relley v. Campbell (1901) 134 Cal. 175, 66 Pac. 220; Commercial Security Co. v. Modesto Drug Co. (1919) 43 Cal. App. 162, 184 Pac. 964; Deming v. Maas (1912) 18 Cal. App. 330, 123 Pac. 204; Rutz v. Obear (1911) 15 Cal. App. 435, 115 Pac. $6 \%$. 